\title{
SENSORY EVALUATION AND MICROBIOLOGICAL CHARACTERIZATION OF AUTOCHTHONOUS SOMBOR CHEESE
}

MIJAČEVIĆ ZORA and BULAJIĆ SNEŽANA

*University of Belgrade, Faculty of Veterinary Medicine, Serbia

(Received 7. February 2008)

In this paper the results of organoleptic evaluation, chemical and microbiological analysis of Sombor cheese were presented. Sombor cheese is a type of autochthonous cheese whose traditional processing method is still in use in areas of northern part of Serbia. The sensory profile, chemical and microbiological analysis were performed on 19 samples of traditionally made chees collected from two households. The sensory evaluation of cheese samples showed its variation in taste and consistency, as well as an unstable cheese flavour. Generally, the traditionally made Sombor cheese in wood modules received a higher score than the cheese produced in the cylindric form. According to the fat content in dry matter Sombor cheese can be classified as a fat cheese and depending of water content in non fat cheese matter, Sombor cheese belongs to the group of soft cheeses. Fat in dry matter and content of total nitrogen showed great variations which indicate the unevenness in technology and unconsistent quality of the raw substrate. Results of microbiological examination showed that lactic acid bacteria were the most abundant flora during manufacturing and early ripening of this cheese. Among them, Lactococci, Lactobacilli and Enterococci represented the main microbial groups of lactic microflora.

Key words: Sombor cheese, sensory evaluation, chemical analysis, microbiological investigation

\section{INTRODUCTION}

There is a growing interest in traditional dairy products, especially cheeses, manufactured at the farm level due in part to the uniqueness of such food and the difficulties in mimicking them on an industrial scale. In a global market, these traditionally produced cheeses are now highly appreciated and are considered to be of premium value because of their flavor characteristics, which are not found in varieties of cheese produced industrially (Garabal, 2007). In Europe, such products are elaborated according to well-established rules governing the production of registered designations of origin. In Serbia, Sombor cheese is one such product. Sombor cheese is a soft cheese traditionally produced from raw 
sheep milk in the northern part of Serbia; it is highly appreciated for its unique flavour and shape. The appearance and taste of cheese loosely reminds of those of famouos cheeses like Trappist and Port de Salut. Historical data showed that earliest record of Sombor cheese dating back to 1748, describing its position on the local market of Novi Sad (Antić, 1969). According to Antić (1969) Sombor cheese was made from ewes' milk obtained from both evening and morning milkings. After mixing the sour evening milk with fresh raw milk, the milk was renneted with powdered rennet, and coagulation took place in 30 minutes. Curd was cut in thick slices and left in brine for 2-3 hours and then transferred into vats with perforated inner walls and bottom and was pressed by a weight equal to that of the curd. Cheese was thereafter transferred to a storage room $\left(15^{\circ} \mathrm{C}-17^{\circ} \mathrm{C}\right)$ to complete ripening up to the age of 1 month. Very few studies have been conducted on Sombor cheese. The influence of various technological parameters on cheese ripening process was studied by many authors (Petrović and Mišić, 1974; Petrović, 1986). The studies regarding microbiological examination was not undertaken. So, now there is a need for a complete characterization of Sombor cheese based on microbiological, physicochemical and biochemical aspects which may permit a comparison with some other soft cheeses.

The traditional cheese-making technique utilized has almost remained unchanged over the years in line with local practice. Nowadays, traditional cheese-making of Sombor cheese still remains at few local farms near Sombor and is being sold at the local market in the cylindric form so called "scheit", or in the wooden module called "kačica". It is well documented (Buchin et al., 1998) that cheeses manufactured from raw milk acquire a more intense flavor than those produced from pasteurized or heat/treated milk; such realization is mainly due to the high levels of native lactic acid bacteria present in raw milk (Grappin and Beuvier, 1997). As a consequence, variability is a major drawback in cheeses manufactured from raw milk which is accounted for, among other causes such as seasonal variations in their indigenous microflora. The aroma/flavour and textural characteristics of cheese depend heavily on the method of production, type of milk and metabolic activities of selected starter organisms, and also diversity of species and strains of local and specific indigenous milk microflora.

Cheese is a dynamic biochemical product and, unlike many processed food products for which stability is essential, it undergoes significant changes during the ripening process. Acidifying Lactococci usually occur as dominant bacteria early in the ripening process. Afterwards their numbers decrease as they give way to Lactobacilli, which, due to their higher versatility for fermentation, can survive in the chees at stages when concentration of major carbohydrates and free water decrease. Apart from the above-mentioned major genera of lactic acid bacteria, other bacteria, including non-starter lactic acid bacteria like Enterococci and nonlactic acid bacteria like Staphylococci, Micrococci and propionic acid bacteria which develop as secondary microbiota, are often responsible for the cheese biochemism. The play a crucial role in the microbial balance in this special living ecosystem (Garabal, 2007).

The aim of the present study was therefore to determine the organoleptic, physicochemical properties of Sombor cheese, an artisanal cheese with 
traditional farmhouse cheese-making technology. The main groups of lactic acid bacteria were also investigated. The quality and overall sensory profile of cheese were estimated in dependency on its characteristic shape and storage period.

\section{MATERIALS AND METHODS}

Sensory evaluation, chemical and microbiological analysis were performed on 19 samples of chees produced in a traditional way in two households (10 samples in the form of "kacica" and 9 samples represented in the cylindric form). The cheeses were analyzed after a ripening period of 10 days. Organoleptic properties and chemical parameters were also determined after a storage period of 30 days at $6^{\circ} \mathrm{C} \pm 1^{\circ} \mathrm{C}$ in order to estimate the durability of final product.

The quality of investigated cheese samples were established on the basis of physicochemical parameters: dry matter (DM), fat in dry matter (FDM), moisture in nonfat substance (MNFS), pH values and titrable acidity.

Dry matter (DM) content in cheese was determined by heating at $105^{\circ} \mathrm{C}$ until constant weight (Harrigan and McCance, 1976). Fat in cheese (F) was determined by Gerber method using a butyrometer with a calibrated range from 0 to $40 \%$. Fat in dry matter (FDM) was calculated as follows:

$\mathrm{FDM} \%=\mathrm{F} \% \times 100 / \mathrm{DM}$.

Total nitrogen (TN) and water soluble nitrogen (WSN), were determined using the Kjeldahl method. The proteolytic index was expressed as the WSN\% of TN.

A trained panel of 6 panellists was used to evaluate the sensory attributes of the cheese. All panellists were experienced in sensory evaluation of cheese texture. The applied panel rated the aroma, colour, taste, texture and overall acceptability of investigated cheese samples by using a 0 to 5 scale. Each of the investigated sensory attributes were scored from 1 to 5 (1:the worst, 5 :the best). Final score was calculated by multiplying with coefficient of significance which represent contribution of individual parameters in the maximum sensory profile (aroma $10 \%$ of maximum sensory profile, colour $5 \%$, taste $50 \%$, texture $20 \%$ and overall acceptability $15 \%$ of maximum sensory profile).

For microbiological analysis, cheese samples $(20 \mathrm{~g})$ were diluted in $180 \mathrm{~mL}$ $2 \%$ sodium citrate solution and homogenized in a stomacher (Bag Mixer, Interscience). Serial dilutions were made in quarter strenght Ringer's solution and plated on specific media for viable counts: thermophilic Lactobacilli on MRS Agar (Merck) at $42^{\circ} \mathrm{C}$ for $48 \mathrm{~h}$, mesophilic Lactococci on M17 Agar (Merck) at $30^{\circ} \mathrm{C}$ for 48h; Enterococci on kanamycin aesculin azide agar (Oxoid) at $37^{\circ} \mathrm{C}$ for $24 \mathrm{~h}$.

\section{RESULTS} (Table 1).

The sensory evaluation of traditionally made Sombor cheese was as follows 
Table 1. Sensory evaluation of traditionally made Sombor cheese after ripening period and after storage period of 30 days at $6^{\circ} \mathrm{C} \pm 1^{\circ} \mathrm{C}$

\begin{tabular}{|l|c|c|c|c|}
\hline \multirow{2}{*}{ Sombor cheese } & \multicolumn{4}{c|}{ Sensory evaluation } \\
\cline { 2 - 5 } & $\mathrm{n}$ & $\mathrm{X} \pm \mathrm{SD}$ & Max & Min \\
\hline \hline "Kacica" & 10 & $91.07 \pm 5.57$ & 100 & 77 \\
\hline Cylindric form & 9 & $78.48 \pm 12.69$ & 95 & 53 \\
\hline $\begin{array}{l}\text { After storage period of } 30 \text { days } \\
\text { at } 6{ }^{\circ} \mathrm{C} \pm 10^{\circ} \mathrm{C}\end{array}$ & 5 & $91.61 \pm 5.18$ & 98.5 & 81 \\
\hline
\end{tabular}

The best scores in the overall sensorial profile were awarded to traditionally manufactured cheeses produced in wood modules ("kacica") which were assigned as $91.07 \%$ of maximum sensory quality. According to the results of sensory evaluation, the cheeses in the cylindric form recieved inferior scores for overall sensory profile and were assigned as $78.48 \%$ of maximum sensory quality. The favourable scores ( $91.61 \%$ of maximum sensory quality) in overall sensory profile were assigned to cheeses evaluated after storage period of 30 days at at $6^{\circ} \mathrm{C} \pm 1^{\circ} \mathrm{C}$.

The contribution of each of the quality parameters in overall sensorial quality of cheese were as follows (Table 2, Table 3)

Table 2. Contribution of individual quality parameters in overall sensorial quality of traditionally made Somor cheese in the form of "kacica"

\begin{tabular}{|l|c|c|c|c|}
\hline \multirow{2}{*}{ Quality parameters } & \multicolumn{4}{|c|}{ Sensory evaluation } \\
\cline { 2 - 5 } & $\mathrm{n}$ & $\mathrm{X} \pm \mathrm{s}$ & $\max$ & $\min$ \\
\hline \hline Aroma & 10 & $9.07 \pm 1.18$ & 10 & 7 \\
\hline Colour & 10 & $4.96 \pm 0.19$ & 5 & 4 \\
\hline Taste & 10 & $43.39 \pm 4.31$ & 50 & 30 \\
\hline Texture & 10 & $18.48 \pm 2.29$ & 20 & 12 \\
\hline Overall acceptability & 10 & $14.78 \pm 0.53$ & 15 & 13.5 \\
\hline
\end{tabular}

The taste as the most important quality parameter received favorouble scores and showed significant deviation comparing the samples of traditionally made Sombor cheese in the form of "kacica".

Table 3. Contribution of individual quality parameters in overall sensorial quality of traditionally made Somor cheese in cylindric form

\begin{tabular}{|l|c|c|c|c|}
\hline \multirow{2}{*}{ Quality parameters } & \multicolumn{4}{|c|}{ Sensory evaluation } \\
\cline { 2 - 5 } & $\mathrm{n}$ & $\mathrm{X} \pm \mathrm{SD}$ & Max & Min \\
\hline \hline Aroma & 9 & $7.44 \pm 2.26$ & 10 & 3 \\
\hline Colour & 9 & $4.92 \pm 0.26$ & 5 & 4 \\
\hline Taste & 9 & $34.81 \pm 8.71$ & 45 & 20 \\
\hline Texture & 9 & $17.04 \pm 2.32$ & 20 & 12 \\
\hline Overall acceptability & 9 & $14.28 \pm 1.85$ & 15 & 12 \\
\hline
\end{tabular}


Autochthothonous Sombor cheese produced in cylindric forms showed significant deviations in taste with high variations, and also significant deviations in cheese aroma. In this case, the unsatisfactory scores for aroma and taste resulted in an overall unfavorouble sensory profile.

At the end of storage period of 30 days at $6^{\circ} \mathrm{C}$ the cheeses were tasted for acceptabilty. The contribution of individual sensorial parameters in the overall sensory profile of investigated cheese samples after a storage period of 30 days at $6^{\circ} \mathrm{C}$ was presented in Table 4.

Table 4. The contribution of individual sensorial parameters in overall sensory profile of traditionally made Sombor cheese kept at $6^{\circ} \mathrm{C}$ for 30 days

\begin{tabular}{|l|c|c|c|c|}
\hline \multirow{2}{*}{ Quality parameters } & \multicolumn{4}{|c|}{ Sensory evaluation } \\
\cline { 2 - 5 } & $\mathrm{n}$ & $\mathrm{X} \pm \mathrm{SD}$ & Max & Min \\
\hline \hline Aroma & 5 & $8.43 \pm 0.94$ & 10 & 7 \\
\hline Colour & 5 & $4.50 \pm 0.48$ & 5 & 3.5 \\
\hline Taste & 5 & $45.00 \pm 4.38$ & 50 & 35 \\
\hline Texture & 5 & $19.86 \pm 0.53$ & 20 & 18 \\
\hline Overall acceptability & 5 & $14.82 \pm 1.20$ & 15 & 12 \\
\hline
\end{tabular}

According to the obtained results it was concluded that during the above mentioned storage period the cheese samples received a more consistent taste, and spreadable texture which represented the characteristic attributes of Sombor cheese. The tested cheese samples received a favourable score for taste.

Sombor cheese is still produced on a small, farmhouse style production level. For the purpose of quality testing based on chemical composition two households were selected characterized by traditional cheese making procedures. The chemical composition of Sombor cheese in wood modules is shown in Table 5.

Table 5. The chemical composition of Sombor cheese ("kacica")

\begin{tabular}{|l|c|c|c|c|}
\hline \multirow{2}{*}{ Chemical parameters } & \multicolumn{4}{|c|}{ Chemical composition } \\
\cline { 2 - 5 } & $\mathrm{n}$ & $\mathrm{X} \pm \mathrm{SD}$ & $\max$ & $\min$ \\
\hline \hline Water & 10 & $55.78 \pm 2.78$ & 58.96 & 50.21 \\
\hline Total solids & 10 & $44.22 \pm 2.78$ & 49.79 & 41.04 \\
\hline Fat in dry matter & 10 & $52.40 \pm 4.36$ & 59.35 & 45.26 \\
\hline Total nitrogen & 10 & $17.16 \pm 2.39$ & 22.67 & 14.50 \\
\hline Water soluble nitrogens & 10 & $1.98 \pm 0.87$ & 3.73 & 0.88 \\
\hline Moisture in nonfat substance & 10 & $72.63 \pm 2.53$ & 77.25 & 68.31 \\
\hline
\end{tabular}

According to the fat content in dry matter Sombor cheese can be classified as fat cheese and depending on water content in non fat cheese matter Sombor cheese belongs to the group of soft cheeses. Total nitrogen and water soluble nitrogen showed significant deviations from mean values probably as the result of 
mixing sheep's and cows' milk. The significant deviations in the content of water soluble nitrogen indicates the different ripening period.

The quality of Sombor cheese in the cylindric form based on chemical composition is shown in Table 6.

Table 6. Chemical composition of Sombor cheese in the cylindric form

\begin{tabular}{|l|r|r|r|r|}
\hline \multirow{2}{*}{ Chemical parameters } & \multicolumn{4}{|c|}{ Chemical composition } \\
\cline { 2 - 5 } & $\mathrm{n}$ & $\mathrm{X} \pm \mathrm{SD}$ & Max & Min \\
\hline \hline Water & 9 & $59.94 \pm 2.78$ & 63.99 & 55.43 \\
\hline Total solids & 9 & $40.06 \pm 2.77$ & 44.57 & 36.01 \\
\hline Fat in dry matter & 9 & $44.50 \pm 4.73$ & 51.18 & 37.49 \\
\hline Total nitrogen & 9 & $17.52 \pm 1.18$ & 19.91 & 16.17 \\
\hline Water soluble nitrogens & 9 & $1.76 \pm 0.40$ & 2.2 & 1.02 \\
\hline Moisture in nonfat substance & 9 & $72.99 \pm 2.04$ & 75.94 & 70.16 \\
\hline
\end{tabular}

Sombor cheese in the cylindric form was characterized by lower values for fat, proteins and water soluble nitrogen in comparison to Sombor cheese in the form of "kacica". The obtained values for moisture in nonfat substance indicates that Sombor cheese is a soft cheese.

The quality of Sombor cheeses after a storage period of 30 days at $6^{\circ} \mathrm{C} / 1^{\circ} \mathrm{C}$ is presented in Table 7 .

Table 7. The chemical composition of traditionally made Sombor cheese after a storage period of 30 days at $6^{\circ} \mathrm{C} \pm 1^{\circ} \mathrm{C}$

\begin{tabular}{|l|c|c|c|c|}
\hline \multirow{2}{*}{ Chemical parameters } & \multicolumn{4}{|c|}{ Chemical composition } \\
\cline { 2 - 5 } & $\mathrm{n}$ & $\mathrm{X} \pm \mathrm{SD}$ & Max & Min \\
\hline \hline Water & 5 & $55.82 \pm 6.58$ & 59.56 & 43.70 \\
\hline Total solids & 5 & $44.88 \pm 6.58$ & 56.30 & 40.44 \\
\hline Fat in dry matter & 5 & $51.96 \pm 3.42$ & 55.95 & 47.08 \\
\hline Total nitrogen & 5 & $17.00 \pm 1.64$ & 19.56 & 15.56 \\
\hline Water soluble nitrogen & 5 & $2.63 \pm 0.42$ & 3.07 & 2.13 \\
\hline Moisture in nonfat substance & 5 & $72.15 \pm 5.36$ & 76.65 & 63.80 \\
\hline
\end{tabular}

The investigated 5 samples of Sombor cheeses after a storage period of 30 days at $6^{\circ} \mathrm{C} \pm 1^{\circ} \mathrm{C}$ were characterized by significant variations in water soluble nitrogen content which indicates the long-term duration of ripening through the storage period.

Proteolysis during cheese ripening has the important role in forming texture, body and flavours in all mature cheeses. The specifity of cheese making has a major impact on intensity of protein degradation, so it was very interesting to determine the proteolytic index of analyzed cheeses in order to evaluate intensity of proteolysis. The proteolytic index of Sombor cheese in cylindric form and cheese samples in wood modules ("kacica") are presented in Table 8 and 9. 
Acta Veterinaria (Beograd), Vol. 58. No. 5-6, 531-541, 2008.

Mijačević Zora and Bulajić Snežana: Sensory evaluation and

Table 8. The proteolytic index of Sombor cheese in cylindric form

\begin{tabular}{|c|c|}
\hline Statistical parameters & Sombor cheese - cylindric form \\
\hline \hline $\mathrm{X} \pm \mathrm{SD}$ & $10.03 \pm 2.02$ \\
\hline $\operatorname{Max}$ & 12.55 \\
\hline $\operatorname{Min}$ & 6.01 \\
\hline
\end{tabular}

Table 9. The proteolytic index of Sombor cheese in the form of "kacica"

\begin{tabular}{|c|c|}
\hline Statistical parameters & Sombor cheese - "kacica" \\
\hline \hline $\mathrm{X} \pm \mathrm{SD}$ & 11.72 \\
\hline $\operatorname{Max}$ & 20.07 \\
\hline $\operatorname{Min}$ & 3.8 \\
\hline
\end{tabular}

The proteolytic index of analyzed cheese samples showed marked variations which indicate the different ripening periods of investigated cheeses.

Sombor cheese is made from raw sheep milk, without addition of starter cultures, using artisanal procedures through relying on colonization by microbial populations associated with the raw material, equipment and local environment. The knowledge of the microbial diversity of this traditional product is in turn fundamental for the attainment of its unique sensory properties. The prevalence of main microbial groups of lactic acid bacteria in investigated cheese samples is presented in Table 10 and 11.

Table 10. Mean counts (log cfu/g \pm standard deviation) of presumptive Lactococci, Lactobacilli and Enterococci in cheeses produced in wooden modules

\begin{tabular}{|c|c|c|c|}
\hline \multirow{2}{*}{$\begin{array}{c}\text { Statistical } \\
\text { parameters }\end{array}$} & \multicolumn{3}{|c|}{ log cfu/g } \\
\cline { 2 - 4 } & Lactococcus spp. & Lactobacillus spp. & Enterococcus spp. \\
\hline \hline $\mathrm{n}$ & 9 & 9 & 9 \\
\hline $\mathrm{X} \pm \mathrm{S}$ & $7.74 \pm 0.63$ & $7.23 \pm 0.45$ & $5.34 \pm 0.79$ \\
\hline $\max$ & 8.32 & 7.96 & 6.45 \\
\hline $\min$ & 6.18 & 6.72 & 4.21 \\
\hline
\end{tabular}

Table 11. Mean counts (log cfu/g \pm standard deviation) of presumptive Lactococci, Lactobacilli and Enterococci in cheeses produced in cylindric forms

\begin{tabular}{|c|c|c|c|}
\hline \multirow{2}{*}{$\begin{array}{c}\text { Statistical } \\
\text { parameters }\end{array}$} & \multicolumn{3}{|c|}{ log cfu/g } \\
\cline { 2 - 4 } & Lactococcus spp. & Lactobacillus spp. & Enterococcus spp. \\
\hline \hline $\mathrm{n}$ & 10 & 10 & 10 \\
\hline $\mathrm{X} \pm \mathrm{s}$ & $8.36 \pm 0.90$ & $6.91 \pm 1.43$ & $6.38 \pm 0.85$ \\
\hline $\max$ & 9.45 & 4.0 & 8.10 \\
\hline $\min$ & 7.93 & 6.72 & 5.10 \\
\hline
\end{tabular}


According to results, lactococci and lactobacilli represented the dominant group of lactic acid bacteria, followed by Enterococci. The Lactococcus spp. reached level of $10^{7}-10^{8} \mathrm{cfu} / \mathrm{g}$, and the microbial counts for presumptive lactobacilli and enterococci attained $10^{6}-10^{7} \mathrm{cfu} / \mathrm{g}$ and $10^{5}-10^{6} \mathrm{cfu} / \mathrm{g}$, respectively.

\section{DISCUSSION}

Sensory quality of cheese is important in determining consumer acceptability. By sensory evaluation, the traditionally made Sombor cheese in the form of "kacica" received higher score than the cheese produced in cylindric forms.

The currently valid regulation define the requirements for the quality of milk and milk products. According to this, the moisture content in non fat substance of Sombor cheese must not be lower than $67 \%$. The fat percentage in dry matter must be $45 \%$ for whole fat cheeses. Briefly, the chemical characteristics of Sombor cheese analyzed in this study met the necessary legal requirements. According to Licitra et al. (2000) cheese composition variation is large due to salt and moisture gradients developed during the ripening period. In our study, marked variations in chemical composition of Sombor cheese were noticed in fat in dry matter and content in total nitrogen which indicated the unevennes in technology and unconsistent quality of. raw substrate. Similarly to our results, Vujičić (1964) pointed out the varible chemical composition of Sombor cheese.

Sombor cheese can be aged up to 1 month, however, it is common to sell the cheese at different ripening period as semi-aged or as an aged cheese. Petrović et al. (1988) investigated the dynamics of total and soluble nitrogen and of individual free aminoacids in order to obtain ripening characteristics of this cheese. As a result of intensive proteolysis, the content of water soluble nitrogen showed typical increase with intensive progress during the first 10 days of ripening and slowly diminish in the later phases of cheese ripening. The data obtained from previous studies show that Sombor cheese achieved the commercial ripeness at the age of 20 to 30 days with the ripening coefficient of 23.66 to 24.76 . Cheeses analyzed in our study represented a wide range of ages and different production facilities so a variation in proteolytic indices would be expected. According to our results, the marked variation in the ripening coefficient (proteolytic index) (3.8-20.07) were mainly due to different ripening periods of the analyzed cheese.

From the microbiological point of view, artisanal cheeses can be considered to be unique ecosystems in terms of considerable variety of lactic acid bacteria types that they contain (Garabal, 2007). In fact, the micro-ecological system prevailing under these conditions differs notably from those in standard cheeses that are produced from pasteurized milk with the addition of well-defined commercial starters (Tavaria and Malcata, 2000). Significant differences in the viable counts of Lactococci, Lactobacilli and Enterococci prone to a wide variability which reflects the intrinsic heterogeneity associated with production and handling. In other studies on raw milk cheeses, the predominance of Lactococci during the early stages of ripening has also been reported (Nunez, 
1978; Litopoulou-Tzanetaki and Tzanetakis, 1992; Centeno et al., 1996). A common feature of Sombor cheeses was a rather high number $(6.91-7.23 \mathrm{log}$ $\mathrm{cfu} / \mathrm{g}$ ) of mesophilic lactobacilli. Mesophilic homofermentative lactobacilli are the principial non-starter lactic acid bacteria (NSLAB) found in many varietes, especially artisanal cheeses. They are the only microbial group which grows well in the hostile environment in the interior of the cheese which has a low pH (5.0), a high salt content (4-6\%), is anerobic and may contains bacteriocins produced by starter bacteria (Fox, McSweney and Lynch, 1998). The presence of Enterococci in relative high numbers in analyzed cheese samples could be due to their tolerance to a wide range of environmental conditions (Mundt, 1986; Garg and Mital. 1992). Enterococci is a group of microorganisms that may influence the ripening process due to their proteolytic and lipolytic activities, and their ability to stimulate acid production by some lactococci (Sarantinopoulos et al., 2001). Similar levels of enterococci have also been reported for white-brined cheeses (Litopoulou-Tzanetaki and Tzanetakis, 1992) and other cheese varieties such as semicotto caprino, an artisanal goat's cheese (Suzzi et al., 2000).

On the basis of our results it was generally concluded that there is a urgent need for standardization of manufacturing processes of Sombor cheese as the main imperative of producing the Sombor cheese of good and consistent quality. In the light of microbiological results it is obvious that the Lactococci, Lactobacilli and Enterococci are well adapted to Sombor cheese environment and can contribute to the physicochemical and sensory characteristics of Sombor cheese.

\section{CONCLUSION}

1. Sombor cheese in the form of "kacica" received a favorouble score of $91.07 \pm 5.57 \%$ of maximum sensory quality, while Sombor cheese in the form of cylindric baskets received the score of $78.48 \pm 12.69$ of maximum sensory quality.

2. Average value of taste acceptability was higher for Sombor cheese in the form of "kacica".

3. According to the fat content in dry matter Sombor cheese can be classified as fat cheese and depending of water content in non fat cheese matter Sombor cheese belongs to the group of soft cheeses.

4. Fat in dry matter and content of total nitrogen showed great variations which indicate the unevennes in technology and unconsistent quality of the raw substrate.

5. Variations in proteolytic index between analyzed cheese samples represented the different ages of cheeses.

6. The main microbial groups of lactic microflora were Lactococci, Lactobacilli and Enterococci. 
Address for correspondence:

Dr Zora Mijačević

Faculty of Veterinary Medicine

Bulevar oslobođenja 18,

11000 Belgrade, Serbia

E-mail:zorami@vet.bg.ac.yu

\section{REFERENCES}

1. Antić $\oslash$, 1969. Istorijat trgovine somborskog sira, Veterinarski glasnik, 10, 779-80.

2. Buchin S, Delague V, Duboz G, Berdague JL, Beuvier E, Pochet S, Grappin R, 1998, Influence of pasteurization and fat composition of milk on the volatile compounds and flavor characteristics of a semi-hard cheese, J Dairy Sci, 81, 3097-108.

3. Centeno JA, Menendez S, Rodriguez-Otero JL, 1996, Main microbial flora present as natural starters in Cebreiro raw cow's milk cheese (Northwest Spain), Int J Food Microbiol, 33, 307-13.

4. Fox PF, McSweeney PLH and Lynch CM, 1998, Significance of non-starter lactic acid bacteria in Cheddar cheese, Austr J Dairy Technol, 53, 5383-9.

5. Garabal $\mathrm{JI}, 2007$, Biodiversity and the survival of autochthonous fermented products, Int Microbiol, 10, 1-3.

6. Garg SK, Mital BK, 1992, Enterococci in milk and milk products, Crit Rev Microbiol, 18, 15-45.

7. Grappin R, Beuvier $E, 1997$, Possible implications of milk pasteurization on the manufacture and sensory quality of ripened cheese, A review, Int Dairy J, 7, 751-61.

8. Harrigan WF, McCance ME, 1976, Laboratory Methods in Food and Dairy Microbiology, Academic Press, London, UK, 136-8.

9. Kosikowski FV, Mistry WV, 1997, Cheese and fermented milk foods, Procedures and Analysis, Vol 2 (F.V. Kosikowski, ed.), Westpont, CT, USA, 208-64.

10. Licitra G, P Campo, M Manenti, G Portelli, S Scuderi, S Cappino and DM Barbano, 2000, Composition of Ragusano cheese during aging, J Dairy Sci, 83, 404-11.

11. Litopoulou-Tzanetaki E, Tzanatakis N, 1992, Microbiological study of white-brined cheese made from raw goat milk, Food Microbiol, 9, 13-9.

12. Mundt JO, 1986, Gram Positive Cocci Enterococci In: Butler, JP (Ed.), Bergey's Manual of Systematic Bacteriology, vol 2, 6th ed, Willams and Wilkins, Baltimore, 1063-5.

13. Nunez M, 1978, Microflora of Cabrales cheese: changes during maturations, J Dairy Res, 45, 501-8.

14. Petrović Dušica, 1986, Uticaj tehnološkog procesa proizvodnje na zrenje somborskog sira, Doktorska disertacija, Beograd.

15. Petrović $D$, Mišić $D, 1974$, Neke izmene u izradi somborskog sira kao prilog poboljšanju kvaliteta, Mljekarstvo, 9.

16. Petrović $D$, Đorđević J, Mišić $D, 1988$, Dinamika rastvorljivih azotnih materija i slobodnih aminokiselina u toku zrenja somborskog sira, Mljekarstvo, 39, 15-21.

17. Sarantinopoulos P, Andrighetto C, Georgalaki MD, Rea MC, Lombardi A, Cogan TM et al., 2001, Biochemical properties of enterococci relevant to their technological performance, Int Dairy J, $11,621-47$.

18. Suzzi G, Caruso M, Lombardi A, Vannini L, Guerzoni ME, Andrighetto $C$ et al., 2000, A survey of the enterococci isolated from an artisanal Italian goat's cheese (semicotto caprino), Int $J$ Food Microbiol, 89, 267-74.

19. Tavaria FK and Malcata FX, 2000, On the microbiology of Serra da Estrela cheese: geographical and chronological considerations, Food Microbiol, 17, 293-304.

20. Vujičić I, 1964, Razvoj i unapređenje somborskog sira, Mljekarstvo, 2, 36-8. 
Acta Veterinaria (Beograd), Vol. 58. No. 5-6, 531-541, 2008.

Mijačević Zora and Bulajić Snežana: Sensory evaluation and

microbiological characterization of autochthonous Sombor cheese

\title{
SENZORNA ANALIZA I MIKROBIOLOŠKA KARAKTERIZACIJA AUTOHTONOG SOMBORSKOG SIRA
}

\author{
MIJAČEVIĆ ZORA i BULAJIĆ SNEŽANA
}

\begin{abstract}
SADRŽAJ
U radu su prikazani rezultati senzorne, hemijske i mikrobiološke analize Somborskog sira. Somborski sir je tip autohtonog sira čija tradicionalna proizvodnja opstaje u severnim delovima Srbije, u okolini Sombora. Procena organoleptičkih karakteristika, hemijska i mikrobiološka analiza je izvedena na 19 uzoraka sira proizvedenih u dva domaćinstva na tradicionalan način, od čega 10 uzoraka sira u obliku kačica sa pečurkom, a 9 u obliku spljoštenog cilindra. $\mathrm{Na}$ osnovu rezultata senzorne analize, tradicionalno proizvedeni Somborski sir u formi kačice je bolje ocenjen u odnosu na sir u obliku spljoštenog cilindra ("scheit"). Prema sadržaju masti u suvoj materiji, Somborski sir se klasifikuje u grupu masnih sireva, a na osnovu sadržaja vode u ostatku bez masti sir pripada grupi mekih sireva. Količina masti u suvoj materiji i sadržaj belančevina u analiziranim uzorcima sira pokazuju velike intervale varijacije što ukazuje na neujednačenost procesa proizvodnje ali i neujednačen sastav sirovine. Rezultati mikrobiološke analize pokazuju da laktokoke, laktobacili i enterokoke predstavljaju dominantne grupe bakterija mleka.
\end{abstract}

